www.nature.com/pj

\title{
Synthesis and properties of a polyrotaxane network prepared from a Pd-templated bis-macrocycle as a topological cross-linker
}

\author{
Masahiro Ogawa, Ayumi Kawasaki, Yasuhito Koyama and Toshikazu Takata \\ Polyrotaxane networks (PRNs) were synthesized by exploiting a Pd-templated bis-macrocycle as a topological cross-linker \\ during radical polymerization of a vinyl monomer. The bis-macrocycle (9) was prepared by combining two macrocycles \\ with a linear linker. Radical polymerization of 4-vinylpyridine in the presence of 9 and a catalytic amount of 2,2'- \\ azobisisobutyronitrile (AIBN) yielded a gelled polymer. The addition of 4-tert-butylstyrene as a vinyl co-monomer to the \\ polymerization system afforded a sufficiently stable gel as the PRN, clearly indicating that 4-tert-butylstyrene was successfully \\ introduced as end-capping moieties of the trunk polymer. The swelling properties of the PRN were evaluated using several \\ solvents. The topological structure and swelling properties of the PRNs were confirmed by a control experiment using a \\ bis-acyclic pincer-type Pd complex (13) as a cross-linker. \\ Polymer Journal (2011) 43, 909-915; doi:10.1038/pj.2011.84; published online 14 September 2011
}

Keywords: metal template; Pd-templated bis-macrocycle; polyrotaxane network; rotaxane; topological cross-linker

\section{INTRODUCTION}

Among networked polymers, polyrotaxane networks (PRNs) that have rotaxane structures on the cross-link points are the most interesting class of cross-linked polymers. The generation of unique properties in a network polymer having rotaxane-like cross-links was predicted by de Gennes; ${ }^{1}$ one such property leads to easy polymer chain sliding. Ito and coworkers synthesized a hydrogel possessing rotaxane structures at the cross-link points ${ }^{2}$ using Harada's cyclodextrin-based polyrotaxane, ${ }^{3}$ and this hydrogel has recently been made practicable (Nissan, Kanagawa, Japan) and NTT docomo (Tokyo, Japan) used a PRN as a coating paint of automobile or mobile phone, which is termed as 'SCRATCH SHIELD'. The coating paint shows self-healing properties to scrapes depending on the high elasticity of PRN.). ${ }^{4,5}$ However, we reported crown ether-based PRNs that exploit strategic rotaxanation as the cross-linking reaction. ${ }^{6-13}$ Although the use of a crown ether as a wheel component allows more precise structures of PRNs than the use of cyclodextrin, the crown ether-based PRN requires the somewhat troublesome synthesis of sec-ammonium axle. To find a simple and widely applicable approach to PRNs, especially toward PRNs containing vinyl polymers, we planned the development of a topological cross-linker that includes a bis-macrocycle moiety to enable efficient penetration of the propagation end of radical polymerization into macrocyclic cavities. We became intrigued in exploiting a $\mathrm{Pd}(\mathrm{II})-$ templated bis-macrocycle based on the metal-templated method that is often used for rotaxane architectures (Scheme 1) ${ }^{14-16}$ because of the following three merits: (1) the coordination bond of the Pd complex with the ligand-containing polymer axle should be the most stable among many intermolecular interactions, such as hydrophobic interactions, hydrogen bonding and electrostatic interactions, which probably maintain the interlocked structure even under polymerization conditions; (2) the Pd complex method should be applicable to macrocycles (as the wheel component) that have a cavity size larger than the size of vinyl polymers, ${ }^{14-16}$ yielding unprecedented PRNs; and (3) the movable distance of the macrocycle along the polymer axle should be easily controlled by manipulating the introduction ratio of a bulky group as the stopper group into the polymer axle. The manipulation of the distance of the macrocycle along the polymer axle can render an ideal scaffold to reveal an inherent sliding effect of the PRN. This paper discloses the synthesis of a Pd-templated bis-macrocycle, its application as a topological cross-linker for vinyl polymers and the evaluation of the properties of the resulting PRNs.

\section{EXPERIMENTAL PROCEDURE}

Materials

The compounds 1, 2, 4 and 7 were prepared according to the literature. ${ }^{17-20}$ Other materials are available commercially and were used without further purification.

\section{Measurements}

${ }^{1} \mathrm{H}$ and ${ }^{13} \mathrm{C}$ nuclear magnetic resonance (NMR) spectra were recorded on a Jeol AL-400 spectrometer (JEOL, Tokyo, Japan) using $\mathrm{CDCl}_{3}, \mathrm{CD}_{3} \mathrm{CN}$ and dimethyl sulfoxide (DMSO)- $\mathrm{d}_{6}$ as solvents, and measurements were calibrated using 

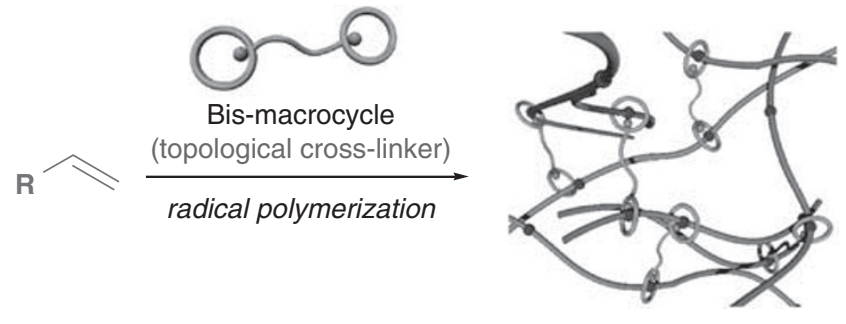

Polyrotaxane Network

Scheme 1 Schematic representation of new synthetic protocol for a polyrotaxane network using a bis-macrocycle. A full color version of this figure is available at Polymer Journal online.

residual non-deuterated solvent or tetramethylsilane as the internal standard (see Supplementary Material). Molecular weights and distributions were estimated by size-exclusion chromatography on a Jasco Gulliver system (JASCO, Tokyo, Japan) equipped with two consecutive linear polystyrene gel columns (Tosoh TSK-gel GMHXL and G5000HXL) at $30^{\circ} \mathrm{C}$ (column flow rate of $0.85 \mathrm{mlmin}^{-1}$ ) according to polystyrene standards using $N, N$-dimethylformamide (DMF) as the eluent. Glass transition temperatures $\left(T_{\mathrm{g}}\right)$ were measured using a Shimadzu DSC-60 instrument (Shimadzu, Kyoto, Japan) under nitrogen (heating rate of $10^{\circ} \mathrm{Cmin}^{-1}$, nitrogen flow rate of $50 \mathrm{ml} \mathrm{min}^{-1}$ ). Thermogravimetric analyses were performed using a Shimadzu TGA-50 instrument under nitrogen (heating rate of $10^{\circ} \mathrm{C} \mathrm{min}^{-1}$, nitrogen flow rate of $\left.50 \mathrm{ml} \mathrm{min}^{-1}\right)$. Fourier transform infrared spectra were recorded on a Jasco FT/IR-460 Plus spectrophotometer (see Supplementary Material). Melting points were measured using a Stuart Scientific SMP3 (Bibby Scientific, Stone, UK). Matrix-assisted laser desorption/ionization-time of flight mass spectrometry spectra were measured with a Shimazdu AXIMA-CFR mass spectrometer using a dithranol matrix. The fast atom bombardment high resolution mass (FAB-HRMS) spectra were requested and obtained from the National University Corporation Tokyo Institute of Technology Center for Advanced Materials Analysis.

\section{Synthesis of 3}

To a mixture of $\mathbf{1}^{17}(5.83 \mathrm{~g}, 22.4 \mathrm{mmol})$ and 4-hydroxybenzylamine $\left(\mathbf{2}^{18}\right)$ $(6.06 \mathrm{~g}, 49.3 \mathrm{mmol})$ in tetrahydrofuran (THF) $(100 \mathrm{ml}), \mathrm{Et}_{3} \mathrm{~N}(17.2 \mathrm{ml}$, $123 \mathrm{mmol}$ ) was added dropwise at room temperature and stirred for $16 \mathrm{~h}$. The mixture was cooled to $0{ }^{\circ} \mathrm{C}$ and neutralized by adding $1 \mathrm{M}$ aqueous $\mathrm{HCl}$. The products were extracted with EtOAc (x3). The combined organic layer was washed with sat. aqueous $\mathrm{NaCl}$, dried over $\mathrm{MgSO}_{4}$, filtrated and concentrated in vacuo. $\mathrm{MeOH}$ was added to the resulting yellow solids and refluxed to yield white solids that were then collected by filtration to give the amide $3(6.54 \mathrm{~g}$, $15.1 \mathrm{mmol}, 67.4 \%)$ as white solids: $\mathrm{mp} 232.8-233.4{ }^{\circ} \mathrm{C}$; ${ }^{1} \mathrm{H} \mathrm{NMR}(400 \mathrm{MHz}$, DMSO-d $\left._{6}, 293 \mathrm{~K}\right) \delta 9.77(\mathrm{t}, J=6.0 \mathrm{~Hz}, 2 \mathrm{H}), 9.30(\mathrm{~s}, 2 \mathrm{H}), 7.71(\mathrm{~s}, 2 \mathrm{H}), 7.12(\mathrm{~d}$, $J=8.4 \mathrm{~Hz}, 4 \mathrm{H}), 6.71(\mathrm{~d}, J=8.4 \mathrm{~Hz}, 4 \mathrm{H}), 6.06(\mathrm{ddt}, J=17.2,10.8,5.2 \mathrm{~Hz}, 1 \mathrm{H})$, $5.42(\mathrm{dd}, J=17.2,1.2 \mathrm{~Hz}, 1 \mathrm{H}), 5.31(\mathrm{dd}, J=10.8,1.2 \mathrm{~Hz}, 1 \mathrm{H}), 4.83(\mathrm{~d}, J=5.2 \mathrm{~Hz}$, 2H), 4.46 (d, J=6.0 Hz, 4H) p.p.m.; ${ }^{13} \mathrm{C}$ NMR $\left(100 \mathrm{MHz}\right.$, DMSO-d $\left.{ }_{6}, 298 \mathrm{~K}\right) \delta$ $166.8,163.0,156.3,150.9,132.4,129.4,128.3,118.2,115.1,110.6,68.8$, 41.7 p.p.m.; IR (KBr) v 3328, 2929, 2812, 2697, 2599, 2478, 2284, 1873, 1752, $1667,1599,1542,1449,1344,1227,1171,997,822,726,691,419 \mathrm{~cm}^{-1}$; FABHR-MS (matrix: NBA) calculated for $\mathrm{C}_{24} \mathrm{H}_{23} \mathrm{~N}_{3} \mathrm{NaO}_{5}{ }^{+}\left[\mathrm{M}+\mathrm{Na}^{+}\right]$: 456.1535, found: 456.1529 .

\section{Synthesis of 5}

To a solution of $3(131 \mathrm{mg}, 0.300 \mathrm{mmol})$ and ditosylate $\left(4^{19}\right)(166 \mathrm{mg}$, $0.330 \mathrm{mmol})$ in DMF $(6.0 \mathrm{ml}), \mathrm{Cs}_{2} \mathrm{CO}_{3}(977 \mathrm{mg}, 3.00 \mathrm{mmol})$ was added at room temperature and stirred for $1 \mathrm{~h}$. The mixture was warmed to $50^{\circ} \mathrm{C}$ and stirred for 3 days. The mixture was cooled to $0{ }^{\circ} \mathrm{C}$ and quenched by adding $\mathrm{H}_{2} \mathrm{O}$. The products were extracted with $\mathrm{CHCl}_{3}(\mathrm{x} 3)$. The combined organic layer was washed with sat. aqueous $\mathrm{NaCl}$, dried over $\mathrm{MgSO}_{4}$, filtrated and concentrated in vacuo. The crude product was purified by column chromatography on silica gel $\left(\mathrm{MeOH}: \mathrm{CH}_{2} \mathrm{Cl}_{2}=1: 20\right)$ to give the corresponding macrocycle 5 (84.3 mg, $0.142 \mathrm{mmol}, 47.2 \%$ ) as white solids: $\mathrm{mp} 170.0-170.7^{\circ} \mathrm{C} ;{ }^{1} \mathrm{H}$

NMR $\left(400 \mathrm{MHz}, \mathrm{CDCl}_{3}, 298 \mathrm{~K}\right) \delta 7.85(\mathrm{~s}, 2 \mathrm{H}), 7.79(\mathrm{t}, J=5.6 \mathrm{~Hz}, 2 \mathrm{H}), 7.15$ (d, $J=8.4 \mathrm{~Hz}, 4 \mathrm{H}), 6.81(\mathrm{~d}, J=8.4 \mathrm{~Hz}, 4 \mathrm{H}), 6.03(\mathrm{ddt}, J=17.2,10.4,5.2 \mathrm{~Hz}, 1 \mathrm{H})$, $5.45(\mathrm{dd}, J=17.2,1.2 \mathrm{~Hz}, 1 \mathrm{H}), 5.34(\mathrm{dd}, J=10.4,1.2 \mathrm{~Hz}, 1 \mathrm{H}), 4.72(\mathrm{~d}, J=5.2 \mathrm{~Hz}$, $2 \mathrm{H}), 4.55(\mathrm{~d}, J=5.6 \mathrm{~Hz}, 4 \mathrm{H}), 4.10-4.04(\mathrm{~m}, 4 \mathrm{H}), 3.90-3.84(\mathrm{~m}, 4 \mathrm{H}), 3.72-3.63$ (m, 8H) p.p.m.; ${ }^{13} \mathrm{C}$ NMR $\left(100 \mathrm{MHz}, \mathrm{CDCl}_{3}, 298 \mathrm{~K}\right) \delta 167.1,163.4,157.6$, $150.3,131.7,130.2,128.5,118.8,114.0,111.4,70.6,70.5,69.5,69.3,67.2$, 42.6 p.p.m.; IR (KBr) v 3300, 2925, 1658, 1615, 1598, 1573, 1515, 1441, 1339, 1230, 1170, 1130, 1104, 1148, 997, 932, 879, 826, 691, 591, $408 \mathrm{~cm}^{-1}$; FAB-HRMS (matrix: NBA) calculated for $\mathrm{C}_{32} \mathrm{H}_{37} \mathrm{~N}_{3} \mathrm{NaO}_{8}\left[\mathrm{M}+\mathrm{Na}^{+}\right]: 614.2478$, found: 614.2499 .

\section{Synthesis of 6}

To a suspension of $10 \% \mathrm{Pd} / \mathrm{C}(0.22 \mathrm{~g})$ in $\mathrm{H}_{2} \mathrm{O}(4.4 \mathrm{ml}), \mathrm{MeOH}(0.1 \mathrm{ml})$ and $\operatorname{DMF}(44 \mathrm{ml}), 5(1.9 \mathrm{~g}, 3.2 \mathrm{mmol})$ and $p$-toluenesulfonic acid $(0.22 \mathrm{~g}, 1.2 \mathrm{mmol})$ were added at room temperature. The mixture was refluxed for $17 \mathrm{~h}$. The mixture was cooled to room temperature and filtered through a Celite pad (Wako, Osaka, Japan). The cake was repeatedly washed with $\mathrm{CHCl}_{3}$. The filtrate was concentrated in vacuo to $\sim 10 \mathrm{ml}$ and washed with sat. aqueous $\mathrm{NaCl}$. The products were extracted with $\mathrm{CH}_{2} \mathrm{Cl}_{2}$. The combined organic layer was dried over $\mathrm{MgSO}_{4}$, filtrated and concentrated in vacuo. The crude product was purified by column chromatography on silica gel $\left(\mathrm{MeOH}: \mathrm{CH}_{2} \mathrm{Cl}_{2}=1: 20\right)$ to give the corresponding macrocycle $6(1.2 \mathrm{~g}, 2.1 \mathrm{mmol}, 64 \%)$ as white solids: $\mathrm{mp}$ 274.2-274.9 ${ }^{\circ} \mathrm{C} ;{ }^{1} \mathrm{H}$ NMR $\left(400 \mathrm{MHz}, \mathrm{DMSO}^{-} \mathrm{d}_{6}, 298 \mathrm{~K}\right) \delta 9.67(\mathrm{t}, J=6.0 \mathrm{~Hz}$, $2 \mathrm{H}), 7.56(\mathrm{~s}, 2 \mathrm{H}), 7.20(\mathrm{~d}, J=8.4 \mathrm{~Hz}, 4 \mathrm{H}), 6.87(\mathrm{~d}, J=8.4 \mathrm{~Hz}, 4 \mathrm{H}), 4.53(\mathrm{~d}$, $J=6.0 \mathrm{~Hz}, 4 \mathrm{H}), 4.04-4.02(\mathrm{~m}, 4 \mathrm{H}), 3.72-3.70(\mathrm{~m}, 4 \mathrm{H}), 3.54-3.33 \quad(\mathrm{~m}$, 8H) p.p.m.; ${ }^{13} \mathrm{C}$ NMR $\left(100 \mathrm{MHz}, \mathrm{DMSO}-\mathrm{d}_{6}, 298 \mathrm{~K}\right) \delta 166.7,163.1,157.4$, 150.8, 131.2, 128.1, 114.2, 111.5, 69.9 (2C), 68.9, 67.2, 41.0 p.p.m.; IR (KBr) $v$ $3368,3081,2925,2885,1676,1659,1612,1540,1515,1444,1347,1300,1251$, 1184, 1125, 1112, 1066, 996, 953, 891, 812, 794, $668 \mathrm{~cm}^{-1}$; FAB-HR-MS (matrix: NBA) calculated for $\mathrm{C}_{29} \mathrm{H}_{33} \mathrm{~N}_{3} \mathrm{NaO}_{8}\left[\mathrm{M}+\mathrm{Na}^{+}\right]$: 574.2165 , found: 574.2166 .

\section{Synthesis of bis-macrocycle (8)}

A mixture of 6 (450 mg, $0.81 \mathrm{mmol}), \mathrm{Cs}_{2} \mathrm{CO}_{3}(470 \mathrm{mg}, 1.4 \mathrm{mmol})$ and 1,8 octane ditosylate $\left(7^{20}\right)(163 \mathrm{mg}, 0.36 \mathrm{mmol})$ in DMF $(3.6 \mathrm{ml})$ was refluxed for $18 \mathrm{~h}$. The solvent was concentrated in vacuo. The crude product was diluted with $\mathrm{CHCl}_{3}$ and washed with $\mathrm{H}_{2} \mathrm{O}$. The aqueous layer was extracted with $\mathrm{CHCl}_{3}$. The combined organic layer was dried over $\mathrm{MgSO}_{4}$, filtrated and concentrated in vacuo. The crude product was purified by column chromatography on silica gel ( $\left.\mathrm{MeOH}: \mathrm{CH}_{2} \mathrm{Cl}_{2}=1: 20\right)$ to give $8(530 \mathrm{mg}, 0.44 \mathrm{mmol}, 54 \%)$ as white solids: $\mathrm{mp} 223.7-224.6^{\circ} \mathrm{C} .{ }^{1} \mathrm{H}$ NMR $\left(400 \mathrm{MHz}, \mathrm{CDCl}_{3}, 298 \mathrm{~K}\right) \delta 7.92$ (t, $J=5.6 \mathrm{~Hz}, 4 \mathrm{H}), 7.83(\mathrm{~s}, 4 \mathrm{H}), 7.09(\mathrm{~d}, J=8.5 \mathrm{~Hz}, 8 \mathrm{H}), 6.75(\mathrm{~d}, J=8.5 \mathrm{~Hz}, 8 \mathrm{H})$, $4.52(\mathrm{~d}, J=5.6 \mathrm{~Hz}, 8 \mathrm{H}), 4.13(\mathrm{t}, J=6.4 \mathrm{~Hz}, 4 \mathrm{H}), 4.08-4.06(\mathrm{~m}, 8 \mathrm{H}), 3.88-3.86$ $(\mathrm{m}, 8 \mathrm{H}), 3.69-3.65(\mathrm{~m}, 16 \mathrm{H}), 1.86-1.23(\mathrm{~m}, 12 \mathrm{H})$ p.p.m.; ${ }^{13} \mathrm{C}$ NMR $(100 \mathrm{MHz}$, $\left.\mathrm{CDCl}_{3}, 298 \mathrm{~K}\right) \delta 168.0,163.2,158.2,150.6,130.0,128.8,114.7,111.3,70.8,70.6$, 69.6, 68.9, 67.6, 42.9, 29.0, 28.7, 25.7 p.p.m.; IR (KBr) v 3567, 3349, 2920, 2870, $1670,1252,1178,1132,1063,1035,996,803 \mathrm{~cm}^{-1}$; FAB-HR-MS (matrix: NBA) calculated for $\mathrm{C}_{66} \mathrm{H}_{80} \mathrm{~N}_{6} \mathrm{NaO}_{16}\left[\mathrm{M}+\mathrm{Na}^{+}\right]$: 1235.5529 , found: 1235.5495 .

\section{Synthesis of 9}

To a solution of $8(81 \mathrm{mg}, 0.067 \mathrm{mmol})$ in $\mathrm{CH}_{3} \mathrm{CN}(2.0 \mathrm{ml}), \mathrm{Pd}(\mathrm{OAc})_{2}(30 \mathrm{mg}$, $0.13 \mathrm{mmol}$ ) was added at room temperature and stirred for $6 \mathrm{~h}$ to give a yellow precipitate. The precipitate was collected by filtration and washed with $\mathrm{CH}_{3} \mathrm{CN}$ repeatedly to give $9(95 \mathrm{mg}, 0.063 \mathrm{mmol}, 95 \%)$ as yellow solids: No $\mathrm{mp}$ (>300 ${ }^{\circ} \mathrm{C}$, decomp.); ${ }^{1} \mathrm{H}$ NMR $\left(400 \mathrm{MHz}, \mathrm{CDCl}_{3}-\mathrm{CD}_{3} \mathrm{CN}(10: 1), 298 \mathrm{~K}\right) \delta$ $7.17(\mathrm{~s}, 4 \mathrm{H}), 7.10(\mathrm{~d}, J=7.6 \mathrm{~Hz}, 8 \mathrm{H}), 6.72(\mathrm{~d}, J=7.6 \mathrm{~Hz}, 8 \mathrm{H}), 4.43(\mathrm{~s}, 8 \mathrm{H}), 4.11$ (t, $J=5.9 \mathrm{~Hz}, 4 \mathrm{H}), 4.03-3.95(\mathrm{~m}, 8 \mathrm{H}), 3.80-3.72(\mathrm{~m}, 8 \mathrm{H}), 3.66-3.56(\mathrm{~m}, 16 \mathrm{H})$, $1.79-1.34(\mathrm{~m}, 12 \mathrm{H})$ p.p.m.; ${ }^{13} \mathrm{C} \mathrm{NMR}\left(100 \mathrm{MHz}, \mathrm{CDCl}_{3}, 298 \mathrm{~K}\right) \delta 170.1,169.2$, 156.8, 154.3, 133.5, 127.7, 113.5, 110.6, 70.3, 70.1, 69.6, 69.4, 67.1, 48.4, 28.7, 28.2, 25.3 p.p.m.; IR (KBr) v 3449, 2863, 1608, 1559, 1447, 1411, 1383, 1340, $1319,1288,1245,1174,1134,1099,1060,1019,923,817,778,749,662,614$, $509 \mathrm{~cm}^{-1}$.

\section{Synthesis of 10}

A suspension mixture of $3(0.20 \mathrm{~g}, 0.46 \mathrm{mmol}), \mathrm{K}_{2} \mathrm{CO}_{3}(0.32 \mathrm{~g}, 2.3 \mathrm{mmol})$ and MeI $(0.28 \mathrm{ml}, 4.6 \mathrm{mmol})$ in DMF $(5.0 \mathrm{ml})$ was stirred at $40{ }^{\circ} \mathrm{C}$ for $18 \mathrm{~h}$ under an argon atmosphere. The mixture was cooled to room temperature and 
concentrated in vacuo. The crude materials were diluted with $\mathrm{CH}_{2} \mathrm{Cl}_{2}$ and washed with water. The products were extracted with $\mathrm{CH}_{2} \mathrm{Cl}_{2}$ (x3). The combined organic layer was washed with sat. aqueous $\mathrm{NaCl}$, dried over $\mathrm{MgSO}_{4}$, filtrated and concentrated in vacuo to give 10 as a yellow oil $(0.19 \mathrm{~g}, 0.41 \mathrm{mmol}$, $88 \%) .{ }^{1} \mathrm{H}$ NMR $\left(400 \mathrm{MHz}, \mathrm{CDCl}_{3}, 298 \mathrm{~K}\right): \delta 8.26(\mathrm{t}, J=6.2 \mathrm{~Hz}, 2 \mathrm{H}), 7.83(\mathrm{~s}$, $2 \mathrm{H}), 7.16(\mathrm{~d}, J=8.4 \mathrm{~Hz}, 4 \mathrm{H}), 6.76(\mathrm{~d}, J=8.4 \mathrm{~Hz}, 4 \mathrm{H}), 6.00(\mathrm{ddt}, J=17.4,10.6$, $5.1 \mathrm{~Hz}, 4 \mathrm{H}), 5.41(\mathrm{dd}, J=17.4,0.4,1 \mathrm{H}), 5.33(\mathrm{dd}, J=10.6,0.4 \mathrm{~Hz}, 1 \mathrm{H}), 4.64(\mathrm{~d}$, $J=5.1 \mathrm{~Hz}, 2 \mathrm{H}), 4.50$ (d, J=6.2 Hz, 4H), 3.84 (s, 6H) p.p.m.; ${ }^{13} \mathrm{C}$ NMR $\left(100 \mathrm{MHz}, \mathrm{CDCl}_{3}, 298 \mathrm{~K}\right) 171.0,167.7,162.5,154.5,135.2,134.0,132.7$, 122.7, 117.5, 115.2, 73.0, 58.9, 46.6 p.p.m.; IR (KBr) v 3303, 3079, 3033, $3003,2962,2930,2835,2550,2488,2058,1885,1733,1678,1653,1609$, $1600,1531,1512,1458,1437,1339,1300,1260,1174,1106,1032,1000,931$, $878,800,750,692,591,518 \mathrm{~cm}^{-1}$; FAB-HR-MS (matrix: NBA) calculated for $\mathrm{C}_{26} \mathrm{H}_{27} \mathrm{~N}_{3} \mathrm{NaO}_{5}\left[\mathrm{M}+\mathrm{Na}^{+}\right]$: 484.1848 , found: 484.1851 .

\section{Synthesis of 11}

To a suspension of $10 \% \mathrm{Pd} / \mathrm{C}(40 \mathrm{mg})$ in a mixed solvent of $\mathrm{H}_{2} \mathrm{O}(0.1 \mathrm{ml})$, $\mathrm{MeOH}(0.1 \mathrm{ml})$ and DMF $(0.9 \mathrm{ml}), 10(0.30 \mathrm{~g}, 0.65 \mathrm{mmol})$ and $p$-toluenesulfonic acid $(40 \mathrm{mg}, 0.21 \mathrm{mmol})$ were added at room temperature. The mixture was refluxed for $17 \mathrm{~h}$. The mixture was cooled to room temperature and filtered through a Celite pad. The cake was washed with $\mathrm{CHCl}_{3}$ repeatedly. The filtrate was concentrated in vacuo to $\sim 10 \mathrm{ml}$ and washed with sat. aqueous $\mathrm{NaCl}$. The aqueous layer was extracted with $\mathrm{CH}_{2} \mathrm{Cl}_{2}$. The combined organic layer was dried over $\mathrm{MgSO}_{4}$, filtrated and concentrated in vacuo. The crude product was purified by column chromatography on silica gel $\left(\mathrm{MeOH}: \mathrm{CH}_{2} \mathrm{Cl}_{2}=1: 20\right)$ to give $11(0.13 \mathrm{~g}, 0.31 \mathrm{mmol}, 64 \%)$ as yellow solids: $\mathrm{mp} 188.8-189.5^{\circ} \mathrm{C} ;{ }^{1} \mathrm{H}$ NMR $\left(400 \mathrm{MHz}, \mathrm{CDCl}_{3}, 298 \mathrm{~K}\right) \delta 10.70$ (brd, $\left.1 \mathrm{H}\right), 8.63(\mathrm{t}, J=5.5 \mathrm{~Hz}, 2 \mathrm{H}), 7.75$ $(\mathrm{s}, 2 \mathrm{H}), 7.10(\mathrm{~d}, J=8.5 \mathrm{~Hz}, 4 \mathrm{H}), 6.69(\mathrm{~d}, J=8.5 \mathrm{~Hz}, 4 \mathrm{H}), 4.40(\mathrm{~d}, J=5.5 \mathrm{~Hz}, 4 \mathrm{H})$, 3.68 (s, 6H) p.p.m.; ${ }^{13} \mathrm{C}$ NMR $\left(100 \mathrm{MHz}, \mathrm{CDCl}_{3}, 298 \mathrm{~K}\right) \delta 167.0,164.1,158.8$, 149.9, 129.6, 129.0, 113.8, 112.8, 55.1, 43.0 p.p.m.; IR (KBr) v 3296, 2960, 2931, $2835,2692,2592,2481,2059,1653,1610,1537,1512,1461,1437,1345,1302$, $1247,1174,1109,1032,997,943,888,818,802,749,693,592,545,517 \mathrm{~cm}^{-1}$; FAB-HR-MS (matrix: NBA) calculated for $\mathrm{C}_{23} \mathrm{H}_{24} \mathrm{~N}_{3} \mathrm{O}_{5}\left[\mathrm{M}+\mathrm{H}^{+}\right]$: 422.1716 , found: 422.1723 .

\section{Synthesis of 12}

A mixture of $11(70 \mathrm{mg}, 0.17 \mathrm{mmol}), \mathrm{Cs}_{2} \mathrm{CO}_{3}(98 \mathrm{mg}, 0.30 \mathrm{mmol})$ and $1,8-$ dibromooctane $(20 \mathrm{mg}, 0.076 \mathrm{mmol})$ in DMF $(0.8 \mathrm{ml})$ was refluxed for $23 \mathrm{~h}$. The mixture was cooled to room temperature and concentrated in vacuo. The crude product was diluted with $\mathrm{CHCl}_{3}$ and washed with $\mathrm{H}_{2} \mathrm{O}$. The aqueous layer was extracted with $\mathrm{CHCl}_{3}$. The combined organic layer was dried over $\mathrm{MgSO}_{4}$, filtrated and concentrated in vacuo. The crude product was purified by column chromatography on silica gel $\left(\mathrm{MeOH}: \mathrm{CH}_{2} \mathrm{Cl}_{2}=1: 20\right)$ to give $12(42 \mathrm{mg}$, $0.044 \mathrm{mmol}, 58 \%)$ as white solids: $\mathrm{mp} 175.5-176.4{ }^{\circ} \mathrm{C} ;{ }^{1} \mathrm{H}$ NMR $(400 \mathrm{MHz}$, $\left.\mathrm{CDCl}_{3}, 298 \mathrm{~K}\right) \delta 8.40(\mathrm{~s}, 4 \mathrm{H}), 7.77(\mathrm{~s}, 4 \mathrm{H}), 7.11(\mathrm{~d}, J=8.4 \mathrm{~Hz}, 8 \mathrm{H}), 6.71(\mathrm{~d}$, $J=8.4 \mathrm{~Hz}, 8 \mathrm{H}), 4.46(\mathrm{~d}, J=5.6 \mathrm{~Hz}, 8 \mathrm{H}), 3.99(\mathrm{t}, J=6.0 \mathrm{~Hz}, 4 \mathrm{H}), 3.69(\mathrm{~s}, 12 \mathrm{H})$, 1.81-1.69 (m, 4H), $1.43-1.26$ (m, 8H) p.p.m.; ${ }^{13} \mathrm{C} \mathrm{NMR} \mathrm{(100} \mathrm{MHz,} \mathrm{CDCl}_{3}$, 298 K) $\delta 167.7,163.6,158.7,150.5,130.1,128.9,113.8,111.3,68.7,55.1,42.8$, 28.8, 28.5, 25.4 p.p.m.; IR (KBr) v 3480, 3308, 2999, 2932, 2854, 2835, 1653, 1601, 1534, 1512, 1458, 1441, 1340, 1302, 1247, 1174, 1129, 1110, 1033, 996, $882,819,752,692,595,517 \mathrm{~cm}^{-1}$; FAB-HR-MS (matrix: NBA) calculated for $\mathrm{C}_{54} \mathrm{H}_{61} \mathrm{~N}_{6} \mathrm{O}_{10}\left[\mathrm{M}+\mathrm{H}^{+}\right]$: 953.4449, found: 953.4479 .

\section{Synthesis of 13}

To a solution of $12(31 \mathrm{mg}, 0.032 \mathrm{mmol})$ in a mixed solvent of $\mathrm{CH}_{3} \mathrm{CN}(1.0 \mathrm{ml})$ and $\mathrm{CHCl}_{3}(1.0 \mathrm{ml}), \mathrm{Pd}(\mathrm{OAc})_{2}(14 \mathrm{mg}, 0.064 \mathrm{mmol})$ was added at room temperature and stirred for $2 \mathrm{~h}$ to give a yellow precipitate. The precipitate was collected by filtration and washed with $\mathrm{CH}_{3} \mathrm{CN}$ repeatedly to give 13 (35 mg, $0.028 \mathrm{mmol}, 88 \%)$ as yellow solids: No $\mathrm{mp}$ was observed $\left(>300^{\circ} \mathrm{C}\right.$, decomp.); ${ }^{1} \mathrm{H}$ NMR $\left(400 \mathrm{MHz}, \mathrm{CDCl}_{3}-\mathrm{CD}_{3} \mathrm{CN}(10: 1), 298 \mathrm{~K}\right) \delta 7.21(\mathrm{~s}, 4 \mathrm{H})$, $7.20(\mathrm{~d}, J=5.4 \mathrm{~Hz}, 8 \mathrm{H}), 6.79(\mathrm{~d}, J=5.4 \mathrm{~Hz}, 8 \mathrm{H}), 4.41(\mathrm{~s}, 4 \mathrm{H}), 4.11(\mathrm{t}, J=5.2 \mathrm{~Hz}$, $4 \mathrm{H}), 3.75$ (s, 12H), 1.86-1.75 (m, 4H), 1.47-1.29 (m, 8H) p.p.m.; ${ }^{13} \mathrm{C}$ NMR $\left(100 \mathrm{MHz}, \mathrm{CDCl}_{3}, 298 \mathrm{~K}\right) \delta 170.2,157.8,154.1,133.3,128.1,116.3,113.2$, 110.5, 69.5, 54.9, 49.1, 28.7, 28.2, 25.3 p.p.m.; IR (KBr) v 3400, 2925, 2852, $2836,2359,2339,1607,1545,1509,1437,1413,1381,1336,1322,1288,1245$, $1173,1098,1031,820 \mathrm{~cm}^{-1}$.

\section{Typical procedure for the preparation of a PRN: synthesis} of PRN (16)

A solution of bicyclic $9(7.5 \mathrm{mg}, 5.0 \mathrm{mmol})$ and 4 -vinylpyridine $(530 \mathrm{mg}$, $5.0 \mathrm{mmol})$ in DMF $(1.4 \mathrm{ml})$ was stirred for $2 \mathrm{~h}$ at room temperature. After 4-tert-butylstyrene $(800 \mathrm{mg}, 5.0 \mathrm{mmol})$ was added, the solution was degassed using the frozen thaw technique repeatedly. AIBN $(8.2 \mathrm{mg}, 10 \mu \mathrm{mol})$ was added to the mixture, and the mixture was warmed to $60^{\circ} \mathrm{C}$ and stirred for $16 \mathrm{~h}$ to give a gel. The obtained gel was swollen in $\mathrm{CHCl}_{3}(10 \mathrm{ml})$ overnight to remove impurities and dried under vacuum to give the corresponding PRN 16 (1.1 g, $82 \%)$ as a reddish gel: No $T_{\mathrm{g}}$ was observed (in the range from 30 to $150{ }^{\circ} \mathrm{C}$ ); $T_{\mathrm{d} 5}$ $227^{\circ} \mathrm{C}$; IR (KBr) v 3434, 3065, 3025, 2958, 2926, 2867, 2713, 2359, 2339, 1933 , $1905,1684,1597,1559,1508,1457,1415,1395,1362,1269,1219,1201,1110$, $1069,1016,993,903,824,799,755,711,668,576 \mathrm{~cm}^{-1}$.

PRN 17: $T_{\mathrm{g}} 143.8^{\circ} \mathrm{C}$; $T_{\mathrm{d} 10} 354.2^{\circ} \mathrm{C}$; IR (KBr) v $3675,3185,3063,3050,3022$, 2957, 2867, 1932, 1905, 1787, 1679, 1597, 1558, 1510, 1474, 1448, 1415, 1362, $1322,1269,1219,1202,1111,1090,1069,1016,993,920,823,754,710,658$, $578 \mathrm{~cm}^{-1}$.

\section{Typical procedure for the preparation of gel 20}

A solution of bis(pincer-type Pd complex) $13(6.2 \mathrm{mg}, 5.0 \mathrm{mmol})$ and 4vinylpyridine $(530 \mathrm{mg}, 5.0 \mathrm{mmol})$ in DMF $(1.4 \mathrm{ml})$ was stirred for $2 \mathrm{~h}$ at room temperature. To the solution was added 4-tert-butylstyrene ( $800 \mathrm{mg}, 5.0 \mathrm{mmol}$ ), and the solution was degassed using the frozen thaw technique repeatedly. AIBN $(8.2 \mathrm{mg}, 10 \mu \mathrm{mol})$ was added to the mixture, and the mixture was warmed to $60^{\circ} \mathrm{C}$ and stirred for $16 \mathrm{~h}$ to give a red gel 20 . When the obtained gel was treated with DMF $(5.0 \mathrm{ml})$ at room temperature, the gel immediately changed to give the corresponding sol containing poly(4-vinylpyridine-co-4tert-butylstyrene) and $\mathbf{1 3 .}$

\section{RESULTS AND DISCUSSION}

Syntheses of Pd-templated bis-macrocyclic 9 and bis(pincer-type Pd complex) 13

Scheme 2 features the synthesis of the Pd-templated bis-macrocycle as the topological cross-linker of vinyl polymers. Treatment of $\mathbf{1}^{17}$ with $2^{18}$ in the presence of $\mathrm{Et}_{3} \mathrm{~N}$ afforded amide 3 in $67 \%$ yield. Macrocyclization of $\mathbf{3}$ and $\mathbf{4}$ under high dilution conditions gave the corresponding macrocycle 5 in $47 \%$ yield. Deprotection of the allyl ether moiety ${ }^{21}$ of 5 and subsequent ether formation with 1,8-octaneditosylate $7^{20}$ gave a bis-cyclic compound $\mathbf{8}$. Successive treatment of $\mathbf{8}$ with $\mathrm{Pd}(\mathrm{OAc})_{2}$ in $\mathrm{CH}_{3} \mathrm{CN}$ afforded the Pd-templated bis-macrocycle 9 in $95 \%$ yield. The structure of 9 was determined by ${ }^{1} \mathrm{H}$ NMR, ${ }^{13} \mathrm{C}$ NMR and infrared spectra.

To clarify the significance of the rotaxane cross-link, we prepared an acyclic bis(pincer-type Pd complex) 13 having a structure similar to $\mathbf{9}$, except for the acyclic structure, in the same manner as the synthesis of 9. Bis-Pd complex 13 was prepared in good yield according to Scheme 3, as determined by ${ }^{1} \mathrm{H}$ NMR, ${ }^{13} \mathrm{C}$ NMR and IR spectra.

\section{${ }^{1} \mathrm{H}$ NMR spectral change of 9 before and after the addition of 4-vinylpyridine to 9}

As we had previously found that the combination of a Pd-templated wheel component with a pyridine-containing axle component enables an efficient formation of rotaxane, ${ }^{14,16}$ we focused on the use of 4vinylpyridine as a vinyl monomer. Thus, before PRN synthesis, we examined the coordination behavior of 4-vinylpyridine to the $\mathrm{Pd}$ of 9 using ${ }^{1} \mathrm{H}$ NMR measurements.

Figure 1 shows the ${ }^{1} \mathrm{H}$ NMR spectral change of 9 before and after addition of 4-vinylpyridine. In spectrum $\mathrm{c}$, the slightly downfieldshifted signal originating from the terminal olefin afforded the direct evidence for the formation of Pd-complex 14. Moreover, the aromatic signals assigned to $\mathrm{Hb}$ and $\mathrm{Hc}$ of $\mathbf{9}$ in spectrum a were upfield-shifted, probably due to the shielding effect of 4 -vinylpyridine placed between the two 1,4-phenylene moieties of the macrocycle. In addition, the 

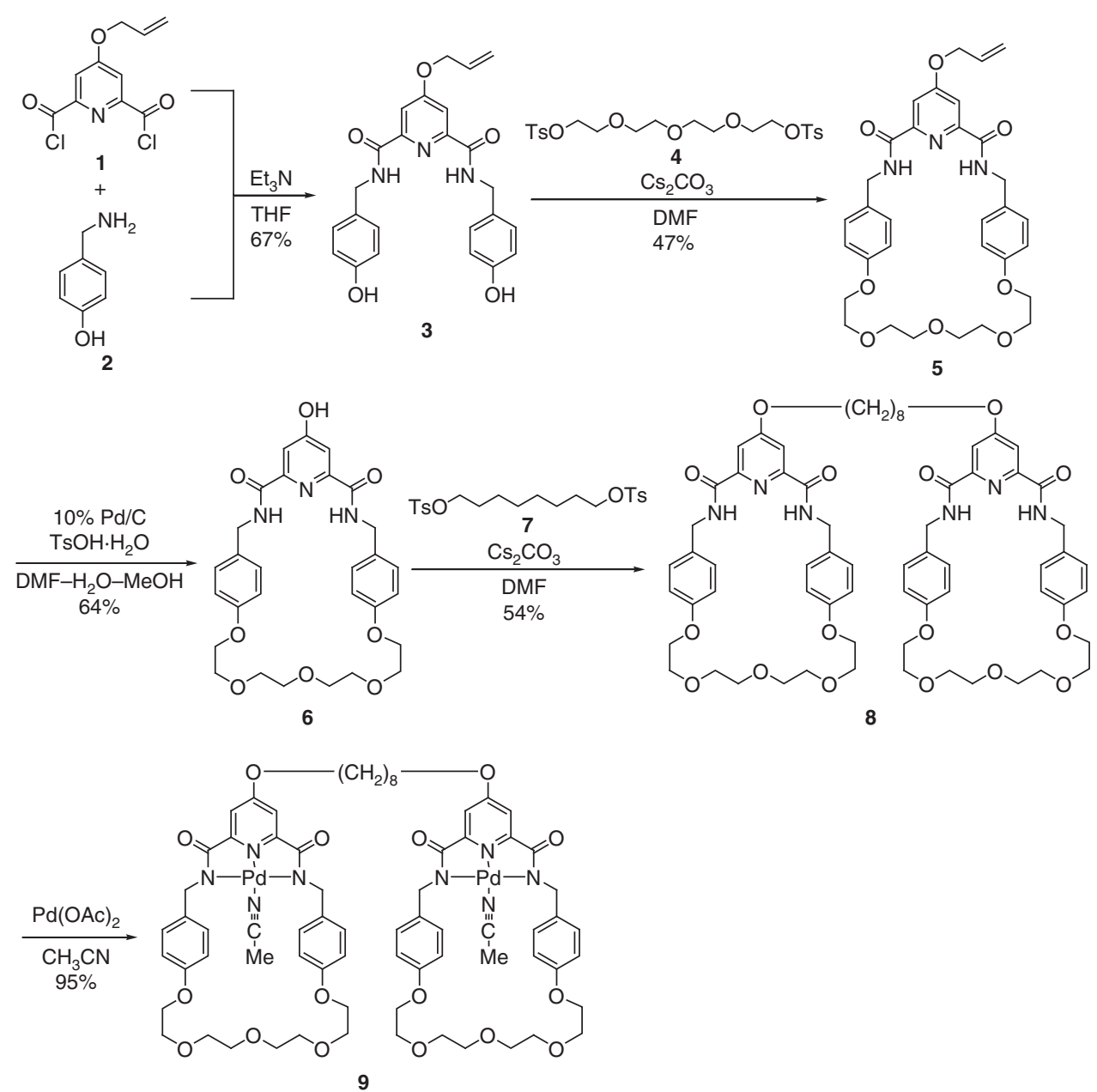

Scheme 2 Synthesis of bis-macrocycle 9.
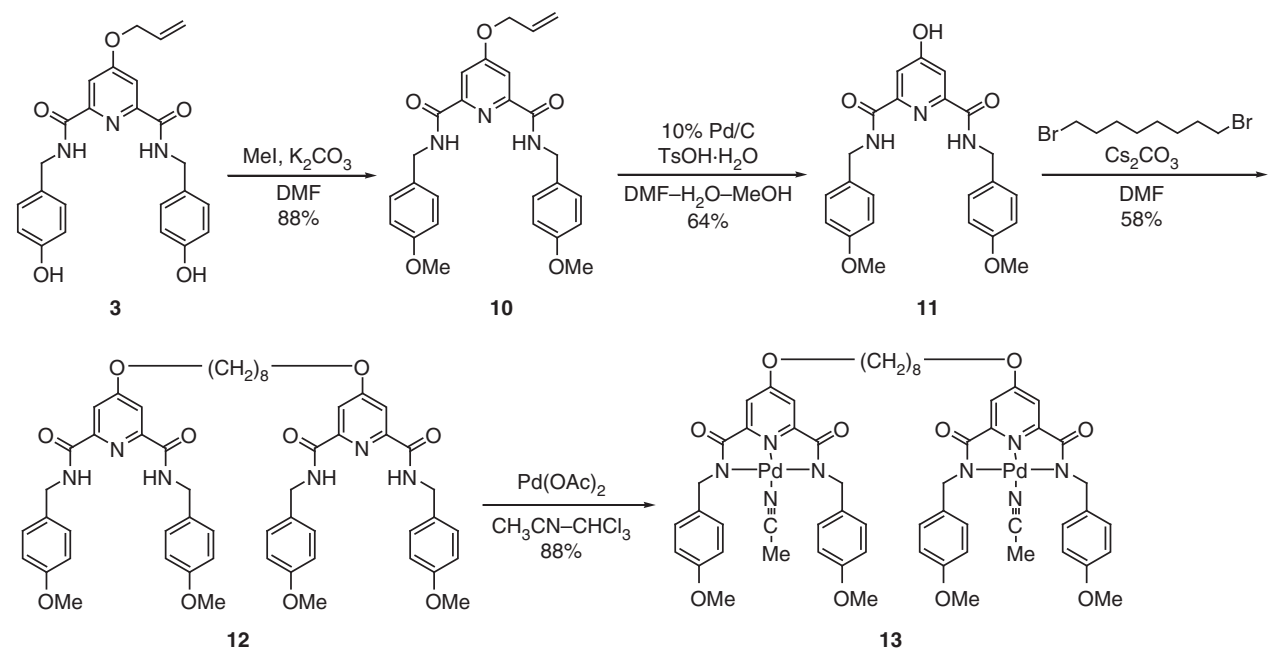

Scheme 3 Synthesis of Bis (Pincer-type Pd complex) 13. 


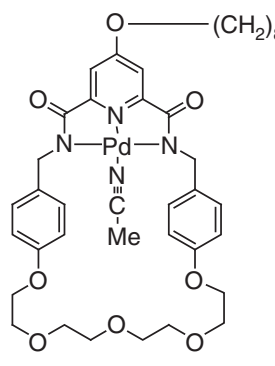

9<smiles>COc1cc(C=O)nc(C(=O)C=O)c1</smiles><smiles>CN(C)[Pb](C)(N)N1CCCCC1</smiles>

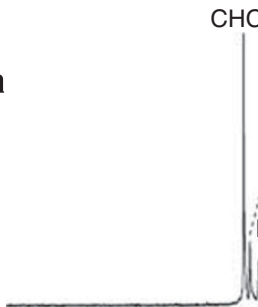

(200 mol\%)

b

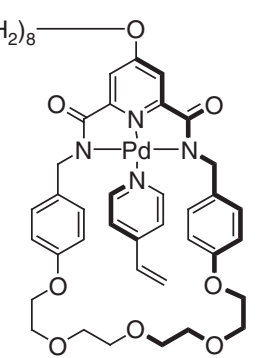

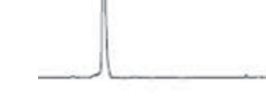

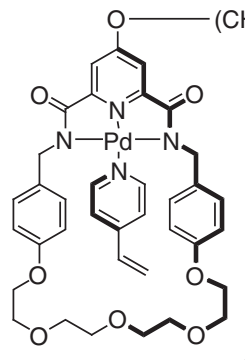

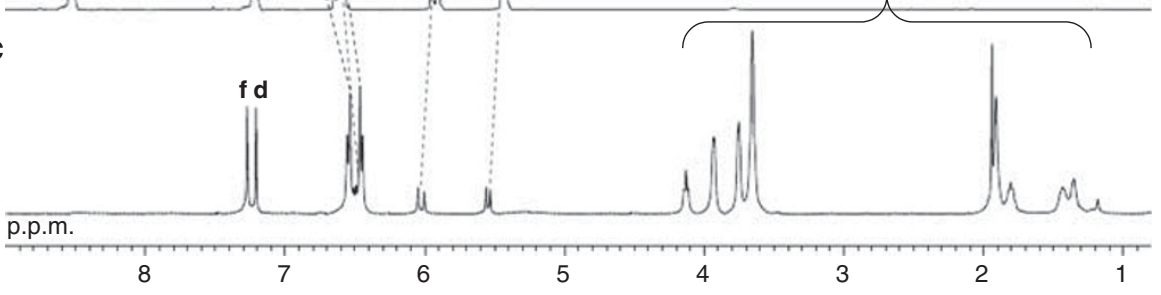

14

Figure $1^{1} \mathrm{H}$ NMR spectra of (a) 9, (b) 4-vinylpyridine and (c) 4-Vinylpyridine-coordinated macrocycle $14\left(400 \mathrm{MHz}, \mathrm{CDCl}_{3}-\mathrm{CD}_{3} \mathrm{CN}(10: 1), 298 \mathrm{~K}\right)$. NMR, nuclear magnetic resonance. A full color version of this figure is available at Polymer Journal online.
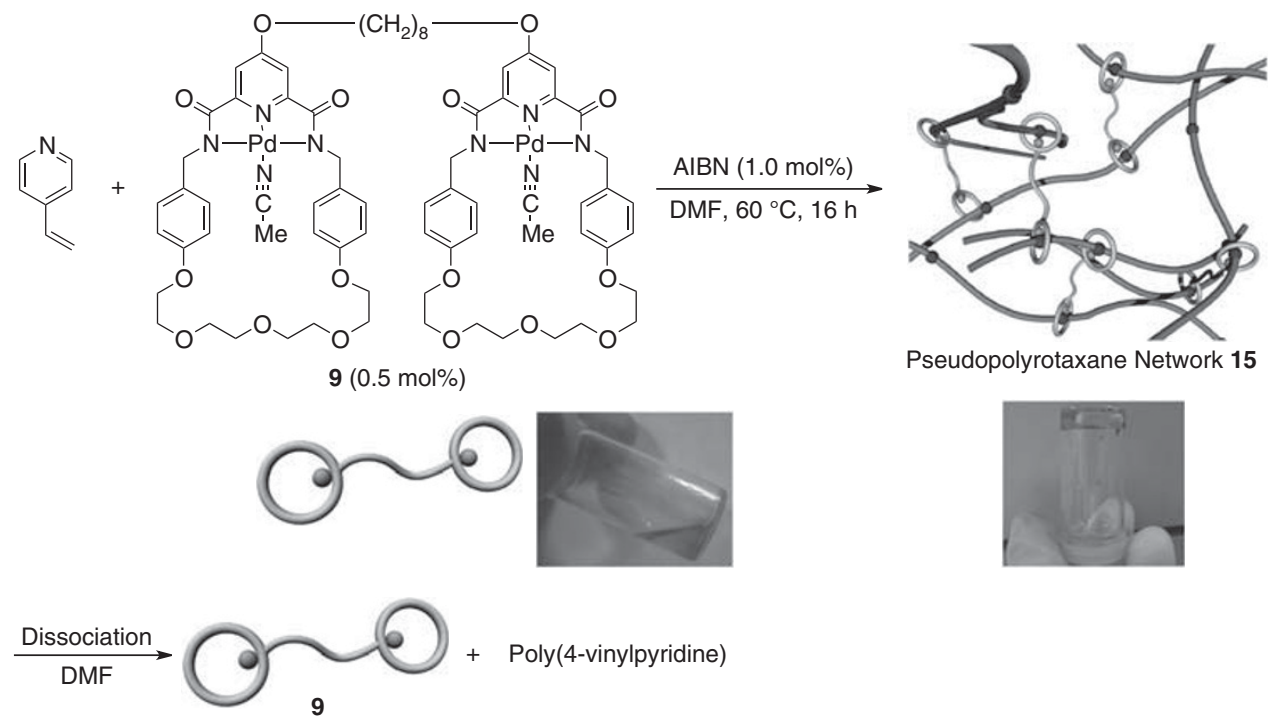

Pseudopolyrotaxane Network 15

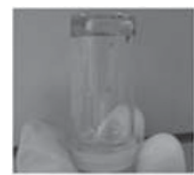

Scheme 4 Formation and dissociation of a pseudo-polyrotaxane network prepared during the radical polymerization of 4 -vinylpyridine in the presence of 9. A full color version of this figure is available at Polymer Journal online.

characteristic signal disappearance of $\mathrm{Ha}$ and $\mathrm{He}$ could be explained by the coalescence based on the slow molecular motion of the macrocycle in accordance with reports in the literature. ${ }^{9}$ These results strongly indicate the formation of inclusion complex 14, which strongly suggests the role of $\mathbf{9}$ as the topological cross-linker for poly(4-vinylpyridine).

\section{Syntheses of PRNs}

The synthesis of the PRN was investigated using the topological crosslinker 9 through the ligand exchange reaction of centered Pd during the radical polymerization of 4-vinylpyridine. Surprisingly, the radical polymerization of 4-vinylpyridine in the presence of small amounts of $9(0.5 \mathrm{~mol} \%)$ and AIBN $(1.0 \mathrm{~mol} \%)$ in DMF at $60^{\circ} \mathrm{C}$ afforded a gelled product in a quantitative yield (Scheme 4 and Table 1, entry 1). The swollen product was assumed to be an organogel derived from poly(4-vinylpyridine) cross-linked by 9 and can be regarded as a pseudo-PRN. However, dilution of the gel with a large amount of DMF led to the prompt dissociation to poly(4-vinylpyridine) and $\mathbf{9}$. This is consistent with the characteristic property of a conventional cross-linked polymer by metal-ligand interactions, strongly indicating 
that the gel includes only topological cross-linking points without any covalent ones.

For preparation of a stable PRN, we next undertook the addition of 4-tert-butylstyrene as a vinyl co-monomer because it is bulky enough to prevent the dissociation of the polyrotaxane components (Scheme 5). Treatment of a 1:1 mixture of 4-vinylpyridine and 4-tertbutylstyrene with AIBN $(1.0 \mathrm{~mol} \%)$ in the presence of $9(0.5 \mathrm{~mol} \%)$ in DMF at $60^{\circ} \mathrm{C}$ for $16 \mathrm{~h}$ afforded a gelled product that was named PRN 16 (Scheme 5 and Table 1, entry 2). The obtained gel kept its shape even under high dilution conditions in DMF, indicating that 4-tert-butylbenzene moieties in the trunk polymer of the gel clearly behave as stopper moieties that prevent the dethreading of the polymer axle from the macrocyclic parts of $\mathbf{9}$. In a similar manner, the radical polymerization of a 1:1 mixture of 4-vinylpyridine and 4-tert-butylstyrene in the presence of twice the amount of 9 ( $1.0 \mathrm{~mol} \%)$ was performed to obtain the highly cross-linked PRN 17 with the rationale that it would provide a sufficiently stable gel. In fact, the solvent-insoluble gel was obtained in a quantitative yield (entry 3 ).

However, it turned out that the addition of 9 to poly(4-vinylpyridine) obtained by the radical polymerization of 4 -vinylpyridine resulted in the formation of an organogel $\mathbf{1 8}$ (entry 4). The result strongly indicates that the gel product formation during polymerization of 4-vinylpyridine in the presence of 9 comes from the thermodynamically controlled formation of the coordination bond between Pd-templated macrocycles and pyridine moieties on the polymer axles

Table 1 Effect of cross-linker and vinyl monomers on the formation of PRNs ${ }^{\mathrm{a}}$

\begin{tabular}{lccccc}
\hline Entry & $\begin{array}{c}\text { Cross-linker 9 } \\
\text { (mol\%) }\end{array}$ & $\begin{array}{c}\text { 4-Vinylpyridine } \\
(\mathrm{mmol})\end{array}$ & $\begin{array}{c}\text { 4-Tert-butylstyrene } \\
(\mathrm{mmol})\end{array}$ & Product & Yield (\%) \\
\hline 1 & 0.5 & 10 & 0 & PRN 15 & 100 \\
2 & 0.5 & 5.0 & 5.0 & PRN 16 & 82 \\
3 & 1.0 & 5.0 & 5.0 & PRN 17 & 100 \\
$4^{c}$ & 0.5 & 10 & 0 & PRN 18 & 100 \\
5 & 0 & 5.0 & 5.0 & 19 & 90 \\
\hline
\end{tabular}

Abbreviation: PRN, polyrotaxane network

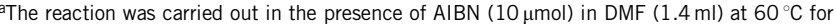
$16 \mathrm{~h}$

$16 \mathrm{~h}$.
bThe yield was a $\mathrm{CHCl}_{3}$-insoluble part.

The reaction was carried out by the addition of 9 after finishing the radical polymerization of 4 vinylpyridine. Poly(4-vinylpyridine-co-4-tert-butylstyrene) $\left(M_{\mathrm{w}} 92000, M_{\mathrm{w}} / M_{\mathrm{n}} 2.1\right)$ was obtained by dissolving the product in large amount of DMF. rather than from the accidental penetration of the propagation end into the macrocyclic cavity of $\mathbf{9}$. In addition, as a control experiment, we examined a radical polymerization reaction without the topological cross-linker 9 under the same conditions (entry 5). As a result, the reaction gave the corresponding linear polymer $19\left(M_{\mathrm{w}} 34000, M_{\mathrm{w}} /\right.$ $M_{\mathrm{n}} 1.4$, estimated by size-exclusion chromatography based on polystyrene standards), supporting the role of $\mathbf{9}$ as a cross-linker.

To clarify the role of the rotaxane cross-links or the significance of the topological cross-linker 9, the polymerization in the presence of bis(pincer-type Pd complex) 13 was investigated (Scheme 6). In a manner similar to that for entry 2 in Table 1, a 1:1 mixture of 4-vinylpyridine and 4-tert-butylstyrene was heated with AIBN $(1.0 \mathrm{~mol} \%)$ at $60^{\circ} \mathrm{C}$ for $16 \mathrm{~h}$ in the presence of $13(0.5 \mathrm{~mol} \%)$ in DMF. A gel 20 obtained in a quantitative yield was treated with a large amount of DMF and immediately changed to a sol containing the trunk polymer (poly(4-vinylpyridine-co-4-tert-butylstyrene)) and $\mathbf{1 3}$. The result surely reveals the importance of the macrocyclic structure of the cross-linker for the formation of stable gelled products.

\section{Swelling behaviors of PRNs}

Table 2 summarizes the percentage swelling ratios of PRNs 16 and 17, which has a more tightly cross-linked structure than 16. PRN 16 was swollen to $5400 \%$ in $\mathrm{CHCl}_{3}$ and to $140 \%$ in $\mathrm{H}_{2} \mathrm{O}$, and this result is consistent with the essential affinity of the trunk polymer toward solvents. All percentage swelling ratios of $\mathbf{1 6}$ in various solvents were bigger than those of 17 , which was in good agreement with the number and movable length of the topological cross-linking points.

\section{CONCLUSIONS}

This article has described the usefulness of the topological cross-linker consisting of Pd-templated bis-macrocycle $\mathbf{9}$, which is widely applicable to cross-linking vinyl polymers. Radical polymerization of 4vinylpyridine in the presence of $\mathbf{9}$ afforded the corresponding PRN, in which the addition of 4-tert-butylstyrene as a vinyl co-monomer gave sufficiently stable gels upon exposure to various solvents. Thus, the present protocol provides a new procedure for preparation of network polymers through the penetration of the propagation end into macrocyclic cavities during radical polymerization. Moreover, this protocol would also render a new manner for introduction of topological characteristics into a desired vinyl polymer. The application to various vinyl polymers and the evaluation of the physical properties of the resulting PRNs would be important future work.

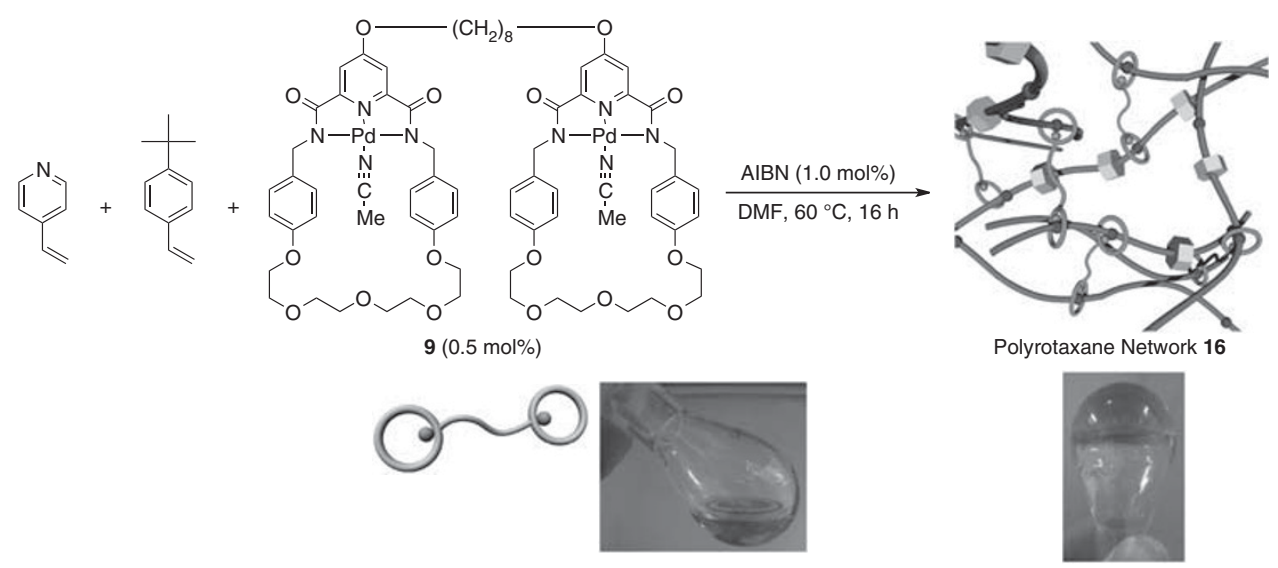

Scheme 5 Polyrotaxane network including end-capping moieties. A full color version of this figure is available at Polymer Journal online. 


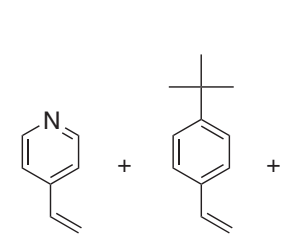

(1: 1)<smiles>C=CN1N=C2C=C(OC)C=C(C(=O)N1Cc1ccc(OC)cc1)N(Cc1ccc(OC)cc1)C2=O</smiles><smiles></smiles>

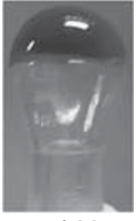

gel 20

13 (0.5 mol\%)
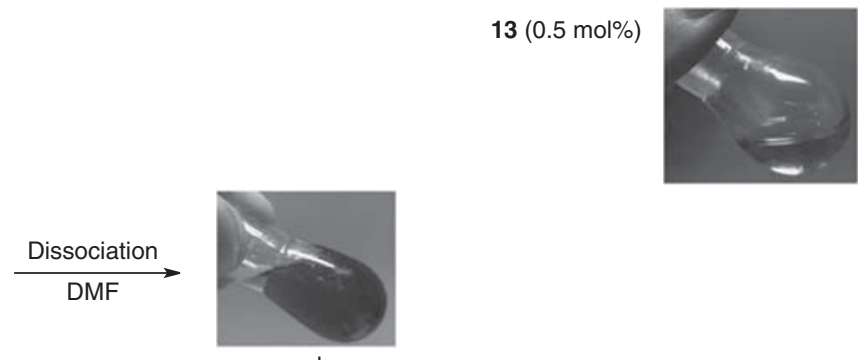

sol

Scheme 6 Formation and dissociation of the Pd-complex Gel 20 using the Bis (Pincer-type Pd complex) 13. A full color version of this figure is available at Polymer Journal online.

Table 2 Swelling behavior of PRNs

\begin{tabular}{lrr}
\hline & \multicolumn{2}{c}{ Percentage swellinga } \\
\cline { 2 - 3 } Solvent & $P R N$ 16 & PRN 17 \\
\hline $\mathrm{H}_{2} \mathrm{O}$ & 140 & 76 \\
$\mathrm{MeOH}$ & 830 & 770 \\
$\mathrm{DMF}$ & 1400 & 970 \\
$\mathrm{CHCl}_{3}$ & 5400 & 4600 \\
\hline
\end{tabular}

Abbreviation: PRN, polyrotaxane network.

aPercentage swelling ratio of a PRN sample $(20 \mathrm{mg})$ immersed in solvent $(5 \mathrm{ml})$ overnight at room temperature. The percentage swelling ratio was calculated according to the following equation: percentage swelling $=($ (weight of swelled gel) $-($ weight of dried gel) $) /($ weight of dried gel) $\times 100$.

\section{CONFLICT OF INTEREST}

The authors declare no conflict of interest.

\section{ACKNOWLEDGEMENTS}

This study was supported by KAKENHI on Innovative Areas (no. 22106511) from the Ministry of Education, Culture, Sports, Science and Technology, Japan.

1 de Gennes, P. G. Sliding gels. Physica A 271, 231-237 (1999).

2 Okumura, Y. \& Ito, K. The polyrotaxane gel: a topological gel by figure-of-eight crosslinks. Adv. Mater. 13, 485-487 (2001).

3 Harada, A., Li, J. \& Kamachi, M. The molecular necklace: a rotaxane containing many threaded $\alpha$-cyclodextrins. Nature 356, 325-327 (1992).

4 Watanabe, J., Ooya, T., Park, K. D., Kim, Y. H. \& Yui, N. Preparation of characterization of poly(ethylene glycol) hydrogels cross-linked by hydrolyzable polyrotaxane. J. Biomater. Sci. Polym. Ed. 11, 1333-1346 (2000).

5 Kihara, N., Hinoue, K. \& Takata, T. Solid-state end-capping of pseudopolyrotaxane possessing hydroxy-terminated axle to polyrotaxane and its application to the synthesis of a functionalized polyrotaxane capable of yielding a polyrotaxane network. Macromolecules 38, 223-226 (2005).

6 Oku, T., Furusho, Y. \& Takata, T. A concept for recyclable cross-linked polymers: topologically networked polyrotaxane capable of undergoing reversible assembly and disassembly. Angew. Chem. Int. Ed. 43, 966-969 (2004).
7 Furusho, Y., Hasegawa, T., Tsuboi, A., Kihara, N. \& Takata, T. 'Unlock-lock' approach to [2] and [3]Rotaxanes: entering of a ring through disulfide linkage that is unlocked by thiol 'key'. Chem. Lett. 29, 18-19 (2000).

8 Furusho, Y., Oku, T., Hasegawa, T., Tsuboi, A., Kihara, N. \& Takata, T. Dynamic covalent approach to [2]- and [3]Rotaxanes by utilizing a reversible thiol-disulfide interchange reaction. Chem. Eur. J. 9, 2895-2903 (2003).

9 Bilig, T., Oku, T., Furusho, Y., Koyama, Y., Asai, S. \& Takata, T. Polyrotaxane networks formed via rotaxanation utilizing dynamic covalent chemistry of disulfide. Macromolecules 41, 8496-8503 (2008).

10 Yoshii, T., Kohsaka, Y., Moriyama, T., Suzuki, T., Koyama, Y. \& Takata, T. An efficient synthetic entry to rotaxanes utilizing reversible cleavage of aromatic disulphide bonds. Supramol. Chem. 23, 65-68 (2011).

11 Takata, T. Polyrotaxane and polyrotaxane network: supramolecular architectures based on the concept of dynamic covalent bond chemistry. Polym. J. 38, 1-20 (2006).

12 Takata, T. \& Otsuka, H. Novel synthetic protocol for supramolecules and polymers by molecular construction and integration based on dynamic covalent chemistry. Yuki Gosei Kagaku Kyoukaishi 64, 194-207 (2006).

13 Kohsaka, Y., Nakazono, K., Koyama, Y. \& Takata, T. Size-complementary rotaxane crosslink: effect on stabilization and degradation of supramolecular network. Angew. Chem. Int. Ed. 50, 4872-4875 (2011).

14 Furusho, Y., Matsuyama, T., Takata, T., Moriuchi, T. \& Hirao, T. Synthesis of novel interlocked systems utilizing a palladium complex with 2,6-pyridinedicarboxamidebased tridentate macrocyclic ligand. Tetrahedron Lett. 45, 9593-9597 (2004).

15 Fuller, A.- M., Leigh, D. A., Lusby, P. J., Oswald, I. D. H., Parsons, S. \& Walker, D. B. A $3 D$ interlocked structure from a $2 D$ template: structural requirements for the assembly of a square-planar metal-coordinated [2]Rotaxane. Angew. Chem. Int. Ed. 43, 3914-3918 (2004).

16 Miyagawa, N., Watanabe, M., Matsuyama, T., Koyama, Y., Moriuchi, T., Hirao, T., Furusho, Y. \& Takata, T. Successive catalytic reactions specific to Pd-based rotaxane complexes as a result of wheel translation along the axle. Chem. Commun. 46, 1920-1922 (2010).

17 Seitz, M., Milius, W. \& Alt, H. G. Iron(II) coordination compounds with $\omega$-alkenyl substituted bis(imino)pyridine ligands: self-immobilizing catalysts for the polymerization of ethylene. J. Mol. Cat. A: Chem. 261, 246-253 (2007).

18 Sinning, C., Watzer, B., Coste, O., Nüsing, R. M., Ott, I., Ligresti, A., Marzo, V. D. \& Imming, P. New analgesics synthetically derived from the paracetamol metabolite $\mathrm{N}$-(4hydroxyphenyl)-(5Z,8Z,11Z,14Z)-icosatetra-5,8,11,14-enamide. J. Med. Chem. 51, 7800-7805 (2008)

19 Mohler, D. L. \& Shen, G. The synthesis of tethered ligand dimers for PPAR $\gamma$-RXR protein heterodimers. Org. Biomol. Chem. 4, 2082-2087 (2006).

20 Nguyen, T. B., Castanet, A.- S., Nguyen, T.- H., Nguyene, K. P. P., Bardeau, J.- F., Gibaud, A. \& Mortier, J. Synthesis of model long-chain $\omega$-alkenyltrichlorosilanes and triethoxysilanes for the formation of self-assembled monolayers. Tetrahedron $\mathbf{6 2}$, 647-651 (2006).

21 Boss, R. \& Scheffold, R. Cleavage of allyl ethers with Pd/C. Angew. Chem., Int. Ed. Engl. 15, 558-559 (1976).

Supplementary Information accompanies the paper on Polymer Journal website (http://www.nature.com/pj) 